\title{
O CONCEITO DE METAFICÇÃO HISTORIOGRÁFICA NO ROMANCE CAIM (2009), DE JOSÉ SARAMAGO
}

\author{
THE CONCEPT OF HISTORIOGRAPHIC METAFICTION IN THE \\ NOVEL CAIM (2009), BY JOSÉ SARAMAGO
}

\section{EL CONCEPTO DE LA METAFICCIÓN HISTORIOGRÁFICA EN LA NOVELA CAIM (2009), DE JOSÉ SARAMAGO}

\section{RESUMO}

O presente trabalho tem por objetivo apresentar uma análise interpretativa acerca do romance Caim, publicado em 2009, por José Saramago. A análise focalizará os aspectos da metaficção historiográfica, termo criado por Linda Hutcheon para designar um novo subgênero que relaciona história e literatura. Nessa obra, Saramago nos apresenta uma nova ótica acerca do Antigo Testamento, refinando com ironia e crítica a história original. Ainda que a Bíblia não seja tida como um documento histórico, ela é considerada como um livro sagrado para a tradição judaicocristã, devido ao seu poder simbólico e ideológico. Desse modo, mesmo não se tratando de um documento histórico, a análise utilizar-se-á dos aspectos da metaficção historiográfica para conduzir as discussões. O trabalho será alicerçado nos pressupostos teóricos acerca da Teoria do Romance, com autores como Hutcheon (1991), Roani (2003), Arnaut (2011) entre outros.

\section{Palavras-chave:}

Metaficção historiográfica;

Literatura Portuguesa; Literatura e História; Caim; José Saramago.

\section{ABSTRACT}

This work aims to present an interpretative analysis about the novel Caim, by José Saramago, published in 2009. The analysis will focus on aspects of historiographic metafiction, a term created by Linda Hutcheon to designate a new subgenre that relates history and literature. In his work, Saramago presents a new perspective on the Old Testament, ironically and critically organizing the original history. Although the Bible is not considered as a historical document, it is regarded as a holy book for the JudeoChristian tradition, because of its symbolic and ideological power. Thus, even if it is not a historical document, the analysis will use aspects of the historiographic metafiction to lead the discussions. Hutcheon (1991), Roani (2003), Arnaut (2011) and others theoretical assumptions about the Theory of the Romance are the basis of this research.

\section{Keywords:}

Historiographic metafiction; Portuguese Literature; Literature and History; Caim; José Saramago.

\section{RESUMEN}

El presente trabajo de investigación tiene como objetivo presentar un análisis interpretativo sobre la novela Caim, publicada en 2009, por José Saramago. El análisis focalizará los aspectos de la metaficción historiográfica, término creado por Linda Hutcheon para designar un nuevo subgénero que relaciona historia y literatura. En esta novela, Saramago nos presenta una nueva óptica sobre el Antiguo Testamento, organizando con ironía y crítica la historia original. Aunque la Biblia no sea considerada un documento histórico, ella es vista como un libro sagrado para la tradición judeocristiana, debido a su poder simbólico e ideológico. Así, aunque no sea un documento histórico, el análisis utilizará los aspectos de la metaficción historiográfica para conducir las discusiones. El trabajo se basará en los presupuestos teóricos sobre la Teoría de la Novela, con los autores Hutcheon (1991), Roani (2003), Arnaut (2011) entre otros.

\section{Palabras clave:}

Metaficción historiográfica;

Literatura Portuguesa; Literatura e Historia; Caim; José Saramago. 


\section{CONSIDERAÇÕES INICIAIS}

Linda Hutcheon, em sua obra A poética do pós-modernismo, publicada em 1988, nos apresenta um novo subgênero que ela denominou como metaficção historiográfica. A crítica coloca esse subgênero como pertencente à estética que ela denomina como pósmodernismo, tentando articular em sua obra, por meio de exemplos como a metaficção historiográfica estaria ligada a essa estética. Por não se tratar do foco do presente artigo, não entraremos no âmbito da discussão acerca das problemáticas do pósmodernismo, nos limitando a discorrer sobre esse subgênero e, aliado a ele, o conceito de paródia.

Na obra já mencionada, Hutcheon, ao propor a metaficção historiográfica como um novo subgênero, suscita reflexões acerca da história, visto que o acesso que se tem a ela é realizado por meio dos documentos históricos, com seus discursos unilaterais que sempre apontam para o centro, isto é, para a cultura dominante. Ao estabelecer uma relação determinada entre literatura e história, a necessidade de se repensar a história se materializaria por meio da metaficção historiográfica que, por sua vez, se manifestaria nos romances, gênero que melhor conseguiria conciliar os paradoxos da ficção e da história sem resolvê-los ou posicionar-se a favor de um. Sobre esse subgênero, a autora postula que: "A metaficção historiográfica procura desmarginalizar o literário por meio do confronto com o histórico, e o faz tanto em termos temáticos como formais" (HUTCHEON, 1991, p. 145). Portanto, o que esse subgênero se propõe a fazer é questionar $\mathrm{o}$ status de legitimidade da história, que assim como a literatura, é construída por meio da linguagem, e ao aliar essas esferas, promove a reflexão acerca da centralidade presente no discurso histórico. Devido ao fato da literatura operar com forma e conteúdo e ambos serem dissociáveis apenas a caráter didático e pedagógico, a metaficção historiográfica consegue atuar nesses dois níveis. Ainda de acordo com a autora:

pós-modernismo é um empreendimento cultural contraditório, altamente envolvido naquilo a que procura contestar. Ele usa e abusa das próprias estruturas e valores que desaprova. A metaficcão historiográfica, por exemplo, mantém a distinção de sua autorepresentação formal e de seu contexto histórico, ao fazê-lo problematiza a própria possibilidade de conhecimento histórico, porque aí não existe conciliação, não existe dialética - apenas uma contradição irresoluta (HUTCHEON, 1991, p. 142).

À vista disso, é possível verificar que a metaficção historiográfica se marca enquanto ficção, assim como determina o contexto histórico ao qual estabelece relações. Ao afirmar esses dois fatores, esse subgênero também problematiza a questão do texto histórico que é justamente a estrutura a qua ela pretende incutir reflexões.

Linda Hutcheon assinala as diferenças existentes entre a metaficção historiográfica e a ficção ou romance histórico. Para melhor esclarecer, a autora traz à baila as palavras de Lukács que presumia que o romance histórico "poderia encenar o processo histórico por meio da apresentação de um microcosmo que generaliza e concentra" (LUKÁCS apud HUTCHEON, 1991, p. 151). A crítica considera que, enquanto no romance histórico o protagonista precisa abarcar uma condensação do geral e do particular, na metaficção historiográfica a operação é inversa, pois em uma de suas modalidades 0 protagonista deve fazer parte dos marginalizados, dos excêntricos, daqueles que ficaram apagados ou silenciados na história[1]. Hutcheon, ainda seguindo os passos de Lukács, elenca três principais diferenças entre o novo subgênero e o romance histórico. A primeira seria que "o romance histórico é definido pela relativa insignificância da utilização que dá ao detalhe" (HUTCHEON, 1991, p. 151-152).

A autora salienta que nem todos os críticos são consoantes a esse posicionamento, que apresenta como fonte primordial o filósofo húngaro. A metaficção historiográfica segundo Hutcheon (1991, p. 152) difere desse aspecto, pois "se aproveita das verdades e das mentiras do registro histórico". A segunda diferença pontuada pela autora é modo como os detalhes e/ou os dados históricos são utilizados. Para a teórica (1991, p. 152), a ficção histórica usufrui realmente desses dados, além de incorporar e assimilar, o que ocasiona uma maior sensação de veracidade. Contrariamente, a metaficção historiográfica incorpora, mas dificilmente os assimila, isso por que ela reconhece que a realidade do 
passado só nos é acessivel por meio dos textos e discursos históricos. A crítica novamente traz o posicionamento de Lukács para definir a terceira característica do romance histórico: "é a relegação dos personagens históricos a papéis secundários" (HUTCHEON, 1991, p. 152). Ainda sobre os personagens do romance histórico, a autora afirma que:

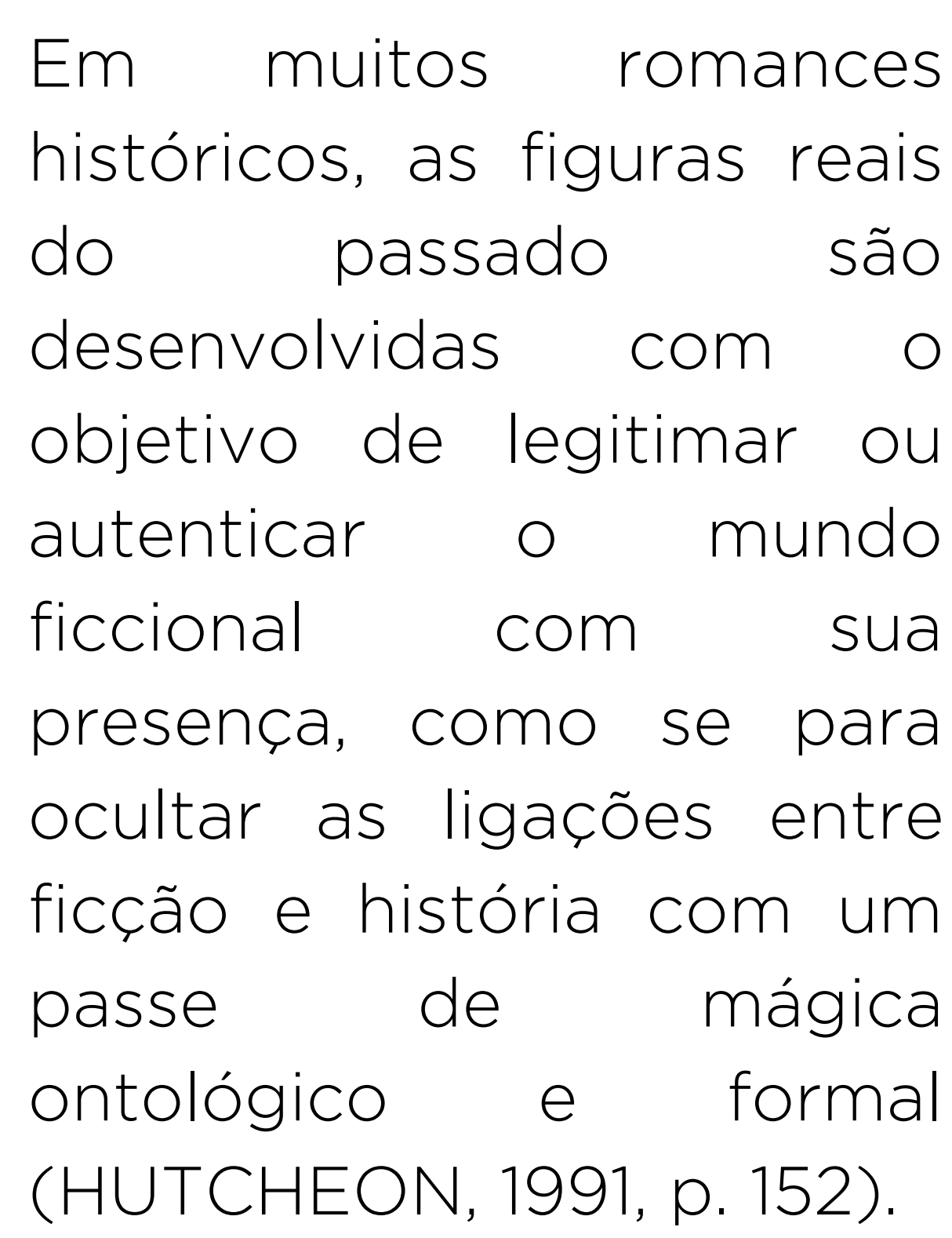

A citação acima vai de encontro com o discutido anteriormente, a respeito da metaficção historiográfica protagonizar os ex-cêntricos e marcar-se enquanto ficção. Relacionandose a isso, evidencia-se que a metaficção historiográfica pode desenvolver-se a partir de duas perspectivas: a primeira quando ocorre o uso de recursos como a paródia e a ironia, para reconstruir determinado momento histórico e por meio dos questionamentos impulsionado por esses elementos promover a reflexão do leitor, e a segunda quando os ex-cêntricos, isto é, os marginalizados e, até então, silenciados pela história alcançam direito à voz na narrativa, diferentemente do que acontece nos romances históricos.

A respeito dessas perspectivas, Linda Hutcheon (1991) detém uma atenção especial à paródia, visto que quando se faz presente na metaficção historiográfica utilizam esse elemento:

não apenas para
recuperar a história e a
memória diante das
distorções da "história do
esquecimento"
(THIHER,1984, 202), mas
também, ao mesmo
tempo, para questionar a
autoridade de qualquer
ato de escrita por meio
da localização dos
discursos da história e da
ficção dentro de uma
rede intertextual em
contínua expansão que
ridiculariza qualquer
noção de origem única ou
de simples causalidade
(HUTCHEON, 1991, p.
169).

A paródia possibilita o questionamento da história ao viabilizar a dubiedade acerca de sua autenticidade. Ao parodiar um texto histórico, o autor possui a alternativa de apresentar ao seu leitor outras perspectivas desvanecidas no discurso oficial. Ao dispor essas novas óticas que irão rebater o discurso singular da história, o autor pode ou não manter um tratamento cerimonioso para com o texto original. Portanto, segundo Hutcheon: "A paródia não é a destruição do passado; na verdade parodiar é sacralizar o passado e questioná-lo ao mesmo tempo" (1991, p. 165). Ao voltar-se para o passado, a paródia acaba por cumprir duas funções, pois por meio desse questionamento, ela acaba colocando-o em voga também, reerguendo-o do esquecimento e inserindo-o nas discussões e reflexões do presente, que não o rebaixam em nenhum sentido, contrariamente, possibilita novas leituras acerca daquele momento histórico.

O pesquisador Gerson Luiz Roani no seu artigo "Espaços que a história tece na ficção de Saramago" discute justamente essa questão do trabalho com os fatos históricos, algo recorrente na obra saramaguiana. A respeito disso o crítico afirma que:

\begin{tabular}{|c|}
\hline 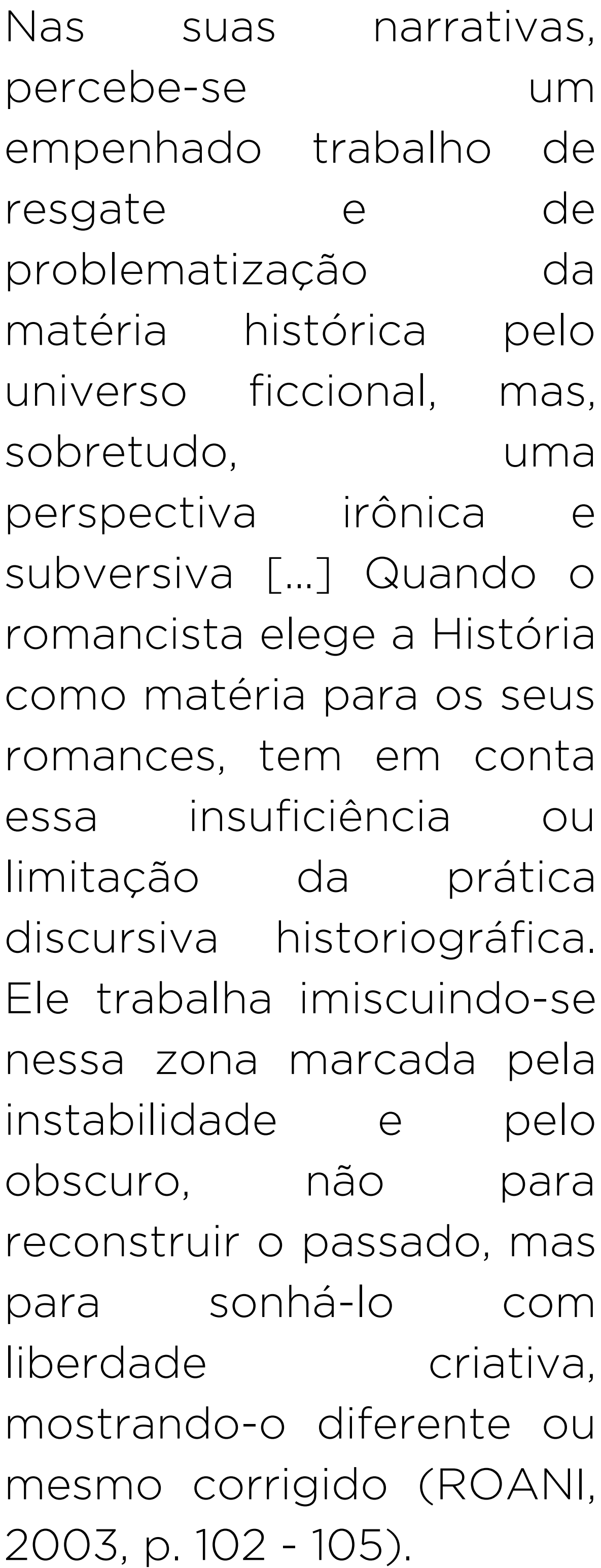 \\
\hline
\end{tabular}

Ao considerarmos a obra de José Saramago em sua totalidade, é possível verificar que essa predileção pelo trabalho com a história é algo recorrente, mas como assinala Roani, não no sentido de restaurar o passado, e sim gozar da liberdade que o literário dispõe e o historiador não e promover uma leitura a contrapelo desses momentos históricos, questionando a hegemonia da história e apresentando novas perspectivas e óticas.

Saramago é um autor singular no que tange a esse processo relacional entre literatura e história. Com efeito, algumas de suas obras podem ser classificadas como metaficção historiográfica, como é o caso do romance Memorial do 
Convento, publicado em 1982, o qual promove uma releitura crítica a respeito da construção do convento de Mafra em Portugal. Além desse romance, inúmeros outros apresentam nuances históricos que foram reescritos a partir do posicionamento do autor como O ano da morte de Ricardo Reis, no qual Saramago traz para a narrativa um dos heterônimos de Fernando Pessoa e História do cerco de Lisboa no qual o protagonista modifica um detalhe histórico no livro que deveria apenas revisar, e promove a reflexão sobre os limites do texto históricos e suas relações com os textos literários. Além desses, o escritor português também se propôs a estabelecer relações com os textos bíblicos cristãos, publicando $O$ evangelho segundo Jesus Cristo em 1991, que trata de uma releitura do Novo Testamento, e posteriormente, em 2009, publicou Caim que pode ser compreendido como uma releitura do Antigo Testamento.

O presente artigo se propõe a analisar o romance Caim a partir dos aspectos da metaficção historiográfica proposto por Linda Hutcheon[2]. Cabe salientar que nossa análise não pretende "encaixar" a obra como metaficção historiográfica ou ainda como paródia da Bíblia, mas sim estabelecer paralelos entre as nuances presentes no romance com 0 conceito formulado pela crítica canadense. É fundamental ressaltar que a Bíblia é um objeto bastante complexo em função de seu duplo estatuto de livro Sagrado e de documento cultural; mesmo não sendo abalizada como um documento histórico tout court, iremos considerar o poder simbólico e ideológico que ela dispõe e a sua influência, que abrange o cristianismo e o judaísmo, estendendo-se ao islamismo e à fé bahá'i[3] e tentaremos demonstrar como o romance realiza uma releitura do texto original por meio da metaficção historiográfica.

Outro desafio importante é a enorme diversidade nas traduções da Bíblia. A edição escolhida apresenta o Imprimatur[4], mas tem certas discrepâncias de outras versões acolhidas pelo Vaticano, de modo a representar um permanente desafio ao seu leitor. Como o objetivo deste texto não é o cotejo de diferentes versões bíblicas, tentaremos modalizar as afirmativas feitas em decorrência do que podem ser variações de tradução.

\section{OS ASPECTOS DE \\ METAFICÇÃO \\ HISTORIOGRÁFICA NA NOVA VERSÃO CONSTRUÍDA POR CAIM}

O romance escolhido como corpus de análise desse artigo apresenta uma representação de Deus bastante diferente daquela que em geral os cristãos e judeus estão familiarizados. $\quad 0$ Deus saramaguiano expõe um lado cruel e maldoso da divindade, que atua como elemento de subversão ao discurso original. Devido à complexidade da obra, é possível verificar inúmeros pontos de contato entre o texto bíblico e o romance, iniciando pelo título da obra, que referencia um personagem bíblico, conhecido no texto original por ter matado seu irmão Abel.

Outro elemento paratextual que enfatiza essa relação é a epígrafe que apresenta Hebreus 11,4: "Pela fé, Abel ofereceu a Deus um sacrifício melhor do que o de Caim. Por causa da sua fé, Deus considerou-o seu amigo e aceitou com agrado as suas ofertas e é pela fé que Abel, embora tenha morrido, ainda fala". É importante notar a ênfase que o discurso da versão bíblica escolhida para este artigo atribui à questão da fé: isso influencia a representação do caráter de Abel. No texto bíblico, porém, não e oferecido nenhum comentário a respeito da escolha divina.

O tom bíblico é de relato factual sem esclarecimentos de motivações nem julgamentos por parte do narrador. Isso abre espaço para fissuras: seria Javé exatamente igual ao Deus cristão, paternal e amoroso? Ou ficaria neste ponto evidente a discrepância entre a deidade tribal, capaz

de

comportamentos

aparentemente inexplicáveis, e o Deus de amor apresentado por Jesus e burilado por São Paulo? O comentário paratextual chega a parecer irônico, uma vez que, na verdade, Abel não fala no texto bíblico original. Sua voz não ecoa, a não ser quando clama a Javé por vingança. A voz de Abel permanece por ter sido, aparentemente, uníssona com a Voz Divina.

Saramago, em seu romance, escolhe aprofundar a fissura e colocar luz em outra perspectiva, dando voz àquele que foi condenado ao silêncio: Caim. A escolha dele como protagonista do romance homônimo implica em um ponto de contato com uma das características da metaficção historiográfica, que é justamente colocar o ex-cêntrico como 
figura principal e com direito à voz e é da fala dele que as críticas mais consistentes advêm. A obra dispõe de um narrador heterodiegético onisciente que, em inúmeros momentos, interage com o leitor e marca a narrativa como uma releitura da história original. Ao lançar uso de um narrador como esse, uma vez mais o romance apresenta um aspecto da metaficção historiográfica, visto que, de acordo com Hutcheon, esse subgênero privilegia dois modos de narrar, sendo "os múltiplos pontos de vista [...] ou um narrador declaradamente onipotente" (1991, p. 156). Caim apresenta-nos a segunda forma de narrar, com um narrador mais que onisciente:

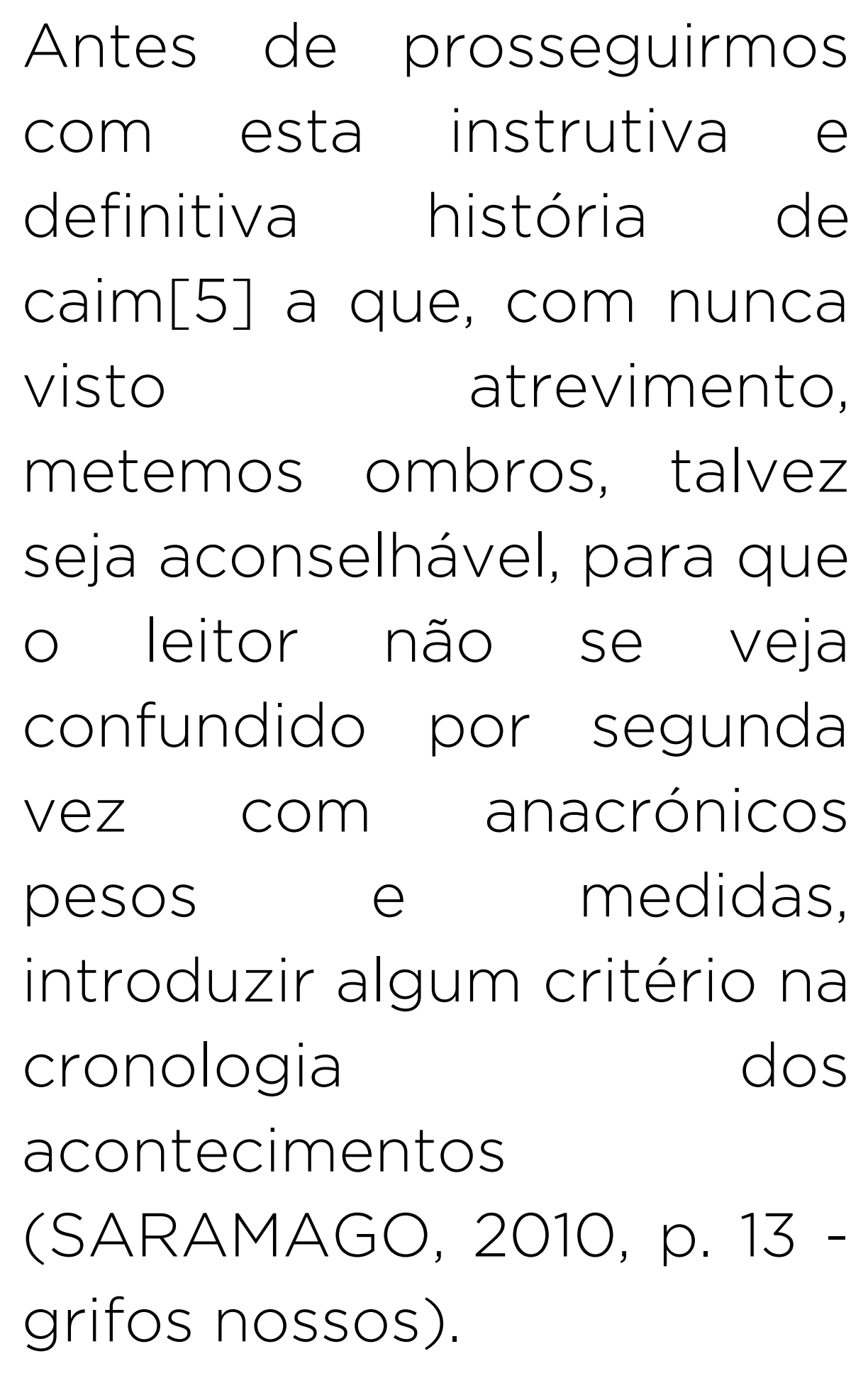

Atentando-nos para o fragmento, em específico para os grifos, é possível verificar que o narrador ao conversar com o leitor marca em sua fala o discurso original, pois explica que essa é a nova história de Caim, o que direciona o leitor a pressupor que exista outra e, ao afirmar sua ousadia em recontála, remete ao texto sagrado. A leitura do romance possibilita compreender que o narrador não se limita a recontá-la, e sim a contá-la a partir de outra ótica. A ironia acentua-se ao afirmar que não pretende confundir o leitor por uma segunda vez, o que nos leva a entender que a leitura do original poderia ser dúbia e encaminhar o leitor para uma interpretação equivocada. Portanto, é verificável que a ironia e a crítica que se fazem presentes no excerto persistirá ao longo do romance, vindo ao encontro com outra característica da metaficção historiográfica, intertextualidade.

Referendando Hutcheon (1991, p. 179), esse recurso pode atuar de duas formas na metaficção historiográfica: pode reforçar a temática e a mensagem do texto original, ou então criticar de forma irônica a autoridade do texto originário. O romance saramaguiano em análise aproxima-se mais da segunda forma, utilizando a história original para, por meio da ironia, construir sua crítica.

De forma indireta, aparece na narrativa a problemática entre o status do texto histórico e o do texto literário: "Ao terceiro, como também ficou dito, chamaram-lhe set, mas esse não entrará na narrativa que vamos compondo passo a passo com melindres de historiador" (SARAMAGO 2010, p. 14).

O narrador marca o processo da narrativa como a construção de um discurso histórico, visto que se utiliza dos melindres de historiador. Vale notar a profunda ironia que tal referência suscita, uma vez que, ao comparar sua história com a história dos historiadores, demonstra o prescindível status de autenticidade que circula ao redor desse tipo de discurso, ou seja, ao introduzir tal referência para o processo de sua narrativa, o autor critica o tratamento dispensado à história oficial, ridicularizando a singularidade do discurso original e afirmando a necessidade de modificar o modo como os textos são lidos e estudados: não é por tratar-se de um texto constituído sobre os princípios da história que este é imutável ou que não possui outro ponto de vista. Entretanto, podemos depreender que essa referência aos historiadores limita-se à crítica:

Quando a criança viesse ao mundo seria para toda a gente o filho de noah [...] - tempo, esse grande igualador, se encarregaria de limar umas e outras, sem contar que os futuros historiadores tomariam a seu cuidado eliminar da crónica da cidade qualquer alusão a um certo pisador de barro chamado abel, ou caim, ou como diabo fosse o seu nome, dúvida esta que, só por si, já seria considerada razão suficiente para o condenar ao esquecimento [...] Este nosso relato, embora não tendo nada de histórico, demonstra a que ponto estavam equivocados ou eram mal-intencionados os ditos historiadores, caim existiu mesmo, fez um filho à mulher de noah (SARAMAGO, 2010, p. 71 grifos nossos)

Uma vez mais, a obra estabelece críticas aos textos fundadores, apontando para aqueles que são destinados a formulá-los, ressaltando o filtro humano pelo qual passa toda a documentação escrita, a qual se configura como o único acesso a essas histórias. A crítica presente na obra de Saramago aproxima-se da metaficção historiográfica, que "demonstra que a ficção é historicamente condicionada e a história é discursivamente estruturada" (HUTCHEON, 1991, p. 158). 
Consoante à postura de Hutcheon, Roani (2003, p. 104) afirma que Saramago compreende que a história não existe por si mesma, mas que se constitui enquanto um produto que, por sua vez, provém de um determinado sujeito, o historiador, que funciona como o crivo que determinará as seleções, as supressões e as interpretações que não conseguirão se distanciar da formação social e ideológica do historiador porque "A História não é simplesmente escrita, ela é feita”. E é justamente essa crítica que se encontra implícita no excerto, ao desmontar a autoridade do historiador e demonstrar o quão humana é a construção da história que aproxima o romance ao conceito de paródia, concernente ao subgênero proposto pela crítica canadense.

No tocante a novas óticas, o romance nos apresenta uma visão diferenciada acerca de inúmeros personagens, com destaque para Caim e Deus. $O$ primeiro ficou conhecido no texto original como a personificação da inveja, já no romance saramaguiano é descrito como: "Esse homem acossado que aí vai, perseguido pelos seus próprios passos, esse maldito, esse fratricida, teve bons princípios como poucos" (SARAMAGO, 2010, p. 38 - grifo nosso) e "Apesar de assassino,

caim é um homem
intrinsecamente honesto" (SARAMAGO, 2010, p. 143). A mesma inversão aplica-se a Deus, uma vez que diferentemente do bíblico, o Deus saramaguiano é caracterizado da seguinte forma: "Então o senhor é rancoroso" (SARAMAGO, 2010, p. 82) e "Um senhor como este, tão cruel como Baal, que devora os seus filhos" (SARAMAGO, 2010, p. 83). Ao longo das análises, pretendemos explicitar essas representações que se diferem do texto original e o modo como elas se configuram como nuances da metaficção historiográfica. Para isso, iniciaremos estabelecendo um paralelo entre ambos os textos. Vamos a eles:

$$
\begin{array}{ll}
\text { Então Javé perguntou a } & \text { isso, Tão ladrão é o que vai } \\
\text { Caim: "Onde está o seu } & \text { à vinha como aquele que } \\
\text { irmão Abel?" Caim } & \text { fica a vigiar o guarda, disse } \\
\text { respondeu: "Não sei. Por } & \text { caim (SARAMAGO, 2010, } \\
\text { acaso eu sou o guarda do } & \text { p. 34-35- grifos } \\
\text { meu irmão?" Javé disse: } & \text { nossos). }
\end{array}
$$
"O que foi que você fez? Ouço o sangue do seu irmão, clamando da terra para mim. Por isso você é amaldiçoado por essa terra que abriu a boca para receber de suas mãos o sangue do seu irmão. Ainda que você cultive o solo, ele não the dará mais o seu produto. Você andará errante e perdido pelo mundo". Caim disse a Javé: "Minha culpa é grave e me atormenta. Se hoje me expulsas do solo fértil, terei de esconder-me de ti, andando errante e perdido pelo mundo; o primeiro que me encontrar me matará". Javé the respondeu: "Quem matar Caim será vingado sete vezes" (BÍBLIA, 1998, p. 17-grifo nosso).

Agora aqui estava vestido como quando expulsou do jardim do éden os infelizes pais destes dois. Tem na cabeça a coroa tripla, a mão direita empunha o ceptro, um balandrau de rico tecido cobre-o da cabeça aos pés. Que fizeste com o teu irmão, perguntou, e caim respondeu com outra pergunta, Era eu o guarda-costas de meu irmão, Mataste-o, Assim é, mas o primeiro culpado és tu, eu daria a vida pela vida dele se tu não ttivesses destruido a minha [...] Sacrilégio, Será, mas em todo o caso nunca maior que o teu, que permitiste que abel morresse, Tu é que o mataste, Sim, é verdade, eu fui o braço executor mas a sentença foi ditada por ti, $O$ sangue que aí estão não o fiz verter eu, caim podia ter escolhido entre o mal e o bem, se escolheu o mal pagará por

Contextualizando os excertos acima, o primeiro é uma das traduções do texto bíblico, mais especificamente de Gênesis 4,915. O segundo fragmento é a releitura que Saramago faz, do mesmo momento. O romance do autor português subverte totalmente a história original. As mudanças no que tange à representação divina começam a diferir já pelo fato de haver descrição das vestimentas do Senhor saramaguiano, que se traja de forma luxuosa, de modo a exaltar a superioridade da sua condição. O leitor de Saramago reconhecerá nesses paramentos suntuosos a inferência crítica característica do autor: Javé está no topo da pirâmide, sua onipotência o coloca acima do bem e do mal. Assemelhado às classes dominantes, ele é incapaz de compreender a dor e a revolta de Caim. Essa crítica é sutil, mas reiterada em outras obras, como em A Caverna, romance no qual as personagens que se deixam seduzir pelo estilo de vida prometido pelo Centro (o shopping center) são surdos às verdades humanas, perfeitos parvenus[6].

Os diálogos entre Caim e Deus iniciam de forma semelhante, 
com o Senhor questionando o mortal sobre o paradeiro de Abel, e aquele respondendo-Ihe que não era sua obrigação cuidar do irmão. A conversação se mantém semelhante até a acusação de Deus, quando, no romance português, Caim se recusa a assumir toda a culpa pela morte do irmão e a atribui a Deus, não cedendo à argumentação do mesmo, uma vez que ele conhece - ou ao menos pressente- o caráter duvidoso de Deus. O crime pelo qual é condenado é o assassinato de seu irmão, que, no texto original, é tido como um bom homem, como ficou explícito no excerto que compõe a epígrafe bíblica. Entretanto, o Abel apresentado na obra difere do ideal de bondade:

Estava claro, o senhor desdenhava caim. Fo então que o verdadeiro caráter de abel veio ao de cima. Em lugar de se compadecer do desgosto do irmão e consolá-lo, escarneceu dele, e, como se isto ainda fosse pouco, desatou a enaltecer a sua própria pessoa, proclamando-se, perante o atónito e desconcertado caim, como um favorito do senhor, como um eleito de deus (SARAMAGO, 2010, p. 33-grifos nossos)

Portanto, a partir da releitura de Saramago, percebe-se a utilização da ironia para estabelecer a crítica de um dos maiores arquétipos da tradição judaico-cristã acerca da representação da bondade no exemplo de Abel e da inveja com Caim como modelo. Evidencia-se a crítica ao maniqueísmo presente no texto original, visto que, na interpretação consagrada pela tradição, o Abel bíblico é totalmente bom e Caim, totalmente mau. Isso é subvertido no romance, pois o Abel saramaguiano se aproveita do favoritismo divino para afirmar-se como superior. Apropriando-se dessa lógica, o autor português realiza 0 mesmo no que tange ao caráter desses dois personagens: Abel e Deus, na Bíblia, apresentam-se com personalidades benignas, mas no romance demonstram um caráter dúbio. O mote para 0 assassinato de Abel no texto originário é a inveja de Caim, ao passo que, no romance, é a arrogância de Abel somada ao fato de que Javé suscita a expressão dessa arrogância ao expor um favoritismo sem mérito. Essa mudança de perspectiva possibilita a reflexão acerca das verdades difundidas pelo cristianismo.

Consoante a essa questão Hutcheon (1991, p. 162) postula que não há uma busca em "'aspirar a contar a verdade (FOLEY, 1986a, 26) tanto quanto aspira a perguntar de quem é a verdade que se conta". Consequentemente, a inserção de uma nova visão sobre Abel possibilita a reflexão sobre a posição de Caim, personagem que, no texto original, só é evidenciado devido à sua falta, pela qual é condenado e, rapidamente, apagado das páginas. Além disso, de acordo com Duby (2011) ele é utilizado como um anti-modelo, isto é, como aquele que não deve ser seguido ou imitado. Pensandose em termos mais próximos aos da antropologia, quando Israel era uma tribo que tentava sobreviver em condições duras, a narrativa de Caim e Abel exorta os jovens a aceitarem as escolhas dos mais velhos: seja o favoritismo baseado em mérito ou não, a revolta do nãoescolhido põe em perigo a sobrevivência do clã. Ao longo da ascensão do cristianismo como religião oficial, a narrativa se transforma numa admoestação contra a inveja e a violência entre irmãos (que deve ter sido especialmente tentadora quando a herança feudal se concentrou nas mãos do filho mais velho, como no século XII na França), bem como prova de que tentar entender os desígnios divinos era pecaminosa.

Na ascensão da burguesia, a mesma narrativa ganha contorno mais esbatido, mas mantém o teor de admoestação contra a rivalidade fraterna e contra o questionamento da vontade divina. Nos séculos $X X$ e XXI, como atesta o paratexto bíblico, surge a necessidade de - comentário atribuir um sentido único, explicando ao seu leitor as razões justas da divindade. Ao atribuir um caráter diferente para Abel, Saramago demonstra a possibilidade de leituras que uma história pode ter e quão contraditórias podem ser, dependendo de qual ponto de vista é narrado.

Outro ponto de contato estabelecido entre 0 texto original e a releitura de Saramago diz respeito ao episódio em que Abraão tenta sacrificar seu próprio e único filho Isaac a pedido do Senhor. O romance Caim apresenta-nos uma versão atualizada sobre tal episódio, no qual o narrador avalia a situação e o protagonista desempenha papel fundamental para que a história permaneça inalterada, isto é, sem Isaac ser sacrificado: 
Leva contigo o teu único filho, Isaac, [...] e oferece-o em sacrifício a mim [...] 0 leitor leu bem, o senhor ordenou a Abraão que the sacrificasse o próprio filho, com a maior simplicidade o fez, [...] o que significa que era costume seu, e muito arraigado. O lógico, o natural, o simplesmente humano seria que Abraão tivesse mandado o senhor à merda, mas não foi assim. [...] Que vai você fazer, velho malvado, matar o seu próprio filho [...] Quem é você, Sou caim, sou o anjo que salvou a vida de Isaac. Não, não era [...] anjo é este que acabou de pousar com um grande ruído de asas e começou a declamar como um ator [...] Chegas tarde, disse caim, se Isaac não está morto foi porque eu o impedi [...] Sinto muito ter chegado atrasado, mas a culpa não foi minha, [...] cá surgiu-me um problema mecânico na asa direita (SARAMAGO, 2010, p. 7980 - grifos nossos).

O narrador chama a atenção do leitor para o despropositado pedido do Senhor, retratando a esperada reação negativa a tal pedido. Contudo, como o próprio narrador marca textualmente não foi essa atitude de Abraão, o que denota a relevância que se atribui ao discurso divino, fazendo com que no texto original, tal pedido não seja encarado como absurdo. Cabe ressaltar que esse tipo de reação contrária não se manifesta no texto original, considerando que toda transgressão era punida, sobretudo no Antigo Testamento. Também merece destaque o tratamento que a obra dispensa ao anjo, que diferentemente do texto originário, configura-se como um ser passível de defeitos técnicos, como o caso da asa que aparenta não the ser inerente, visto que o problema que o anjo alega ter tido tinha a natureza mecânica, algo até então impensável de acordo com o texto bíblico. Saramago usa recursos irônicos não somente para obter um efeito de degradação da divindade mas, principalmente, para tornar o divino uma espécie de metáfora dos sistemas sociais baseados em pirâmides de poder e numa burocracia insensata. $\bigcirc$ problema mecânico não apenas ridiculariza a pressuposta onipotência divina, visto que Deus não estava presente, mas também faz ecoar a humanidade metaforizada na Corte Celestial, isto é apresenta traços humanos nos seres divinos.

O fato de o anjo agir como um ator, ao declamar um discurso pronto para que Abraão não sacrifique o seu filho, reitera a subversão da representação convencional, aproximando mais o anjo do ser humano do que da criatura divina. Ana Paula Arnaut, em seu artigo "Novos rumos na ficção de José Saramago: os romances fábula", afirma que Saramago "Mantendo embora as linhas gerais do que a tradição diz ter acontecido, 0 texto saramaguiano (re)cria uma nova $h(H)$ istória, inscrevendo um desfecho alternativo em nada isento de interessantíssimas subversivas implicações ideológicas" (2011, p. 32). É verificável que o autor valeu-se da tradição bíblica para recontar algumas passagens e que, pela ironia, a crítica presente no texto torna-se evidente, o que possibilita analisar as subversões que a obra propõe, aproximando-se, assim, de alguns pressupostos da metaficção historiográfica.
Ao longo da narrativa, cada vez mais, Caim decepciona-se com Deus, percebendo o caráter maldoso deste. Outros episódios são retomados na história saramaguiana, como a destruição das cidades de Sodoma e Gomorra e a morte de três mil homens por conta da elaboração de um ídolo em formato de carneiro de ouro. A respeito de tantas mortes, às quais a responsabilidade remonta a Deus, o protagonista começa a refletir sobre sua situação e sobre a falta de decoro divina:

Eu não fiz mais que matar
um irmão e o senhor
castigou-me, quero ver
agora quem vai castigar o
senhor por estas mortes,
pensou caim, e logo
continuou, Lúcifer sabia
bem o que fazia quando se
rebelou contra Deus, há
quem diga que o fez por
inveja e não é certo, o que
ele conhecia era a maligna
natureza do sujeito
(SARAMAGO, 2010, p. 101-
grifos nossos).

A partir do posicionamento de Caim, é possível depreender que - mesmo não aceita a figura divina como superior e a coloca como igual: se ele próprio havia cometido um crime e havia sido condenado, Deus também merecia castigos contra os muitos mais numerosos crimes que cometera. As reflexões trazem à baila ainda outra figura, a do anjo caído. $\mathrm{Na}$ tradição judaico-cristã, Lúcifer é conhecido por ter deixado de ser um servo de Deus, o Anjo da Luz, haver liderado uma rebelião, ter sido derrotado e banido do céu. Considerando a nova representação divina que o romance Caim demonstra, é necessário, uma vez mais, reconsiderar e avaliar o outro lado da situação. O protagonista apresenta uma possível 
justificativa para o afastamento de Lúcifer que, contrariando o texto original, não reside na falta de caráter do anjo, e sim no caráter duvidoso do Senhor.

\section{Outro}

questionamento

levantado no romance, diz respeito à onipotência de Deus: "Castiga-os, Estão fora da minha lei, fora da minha alçada, não Ihes posso tocar, é que a vida de um deus não é tão fácil quanto vocês crêem, um deus não é senhor daquele contínuo quero, posso, mando que se imagina, nem sempre pode ir direito aos fins" (SARAMAGO, 2010, p. 119 grifos nossos). Ao colocar em questão a onipotência do Senhor, o romance saramaguiano insurge-se duramente contra $O$ poder simbólico e ideológico da Bíblia, uma vez que é devido a essa imagem autoritária que as relações de poder se desenvolvem. Ao apresentar um Deus não tão poderoso assim, é possivel relacionar as demais fraquezas que essa figura demonstra, como a maldade, a cólera e a arrogância. A representação divina no romance aproxima-se muito mais das características inerentes ao ser humano do que aquelas postuladas como sendo das divindades no texto original. Ao trazer Deus para o patamar do humano, a obra desvela uma forte crítica à superioridade que o poder simbólico atribui à figura de Deus.

Como último episódio, o romance apresenta a arca e o dilúvio. No texto original, devido à maldade que imperava na terra, Deus decide que é necessário iniciar uma nova humanidade, incumbindo a Noé a missão de construir a arca e, posteriormente, junto com sua família, repovoar o mundo. Cabe ressaltar que, no texto original, apenas a família de Noé tem lugar na barca como representantes da espécie humana. Já no romance Caim, há um passageiro a mais. Atentemo-nos aos excertos: "Javé disse a Noé: 'Entre na arca com toda a sua família, por que você é o único justo que encontrei nesta geração", (BÍBLIA, 1998, p. 20 - grifo nosso). $\quad \mathrm{Na}$ obra do autor português, por sua vez, há outra versão: "És um servo leal, fiz bem em escolher-te, Obrigado, senhor, e, se me permitis a pergunta, que faço agora com este homem, Leva-o na barca e junta-o à família" (SARAMAGO, 2010, p. 150 grifo nosso). É sintomático o fato de a releitura incluir Caim junto à arca, considerando que o projeto de Deus, de iniciar uma nova humanidade sem maldade permaneceu em ambos os textos. Ao acrescentar o protagonista, o romance homônimo enfatiza esse caráter diferenciado dele e, ao mesmo tempo, a hipocrisia do Senhor que deseja uma humanidade sem maldade, aquela que ele mesmo possui. A construção da arca também evidencia outras falhas do Senhor:

Os teus cálculos estão errados, um barco deve ser construído junto à água, não num vale rodeado de montanhas, a uma distância enorme do mar, quando está terminado empurra-se para a água e é o próprio mar, ou o rio, se for esse - caso, que se encarregam de o levantar [...] Permite, senhor, que eu expresse o meu pensamento, disse Noé, Fala, disse deus, manifestamente contrariado, caim tem razão, senhor, se ficarmos aqui à espera de que a água nos levante acabaremos por morrer todos afogados e não poderá haver outra humanidade (SARAMAGO 2010, p. 152)

O trecho acima utiliza o conhecimento científico para ironizar esse episódio da história original, devido à impossibilidade da arca flutuar de acordo com os planos divinos, exaltando que Deus também era passível de errar, característica essencialmente humana. Também se faz evidente a contrariedade do Senhor em ter que admitir seu erro, o que pode ser relacionado com esse novo caráter de superioridade, uma vez que o Deus saramaguiano gosta de exaltar-se como superior aos mortais. Pode-se também interpretar como um tipo de fraqueza que o Deus bíblico não apresenta, visto que esse nunca erra. Além disso, ao colocar Caim na arca, o Deus saramaguiano não é capaz de presumir que isso acarretará a destruição de seu plano de uma nova humanidade.

Noé, noé por que não sais. Vindo do escuro interior da arca, caim apareceu no limiar da grande porta, Onde estão noé e os seus, perguntou o senhor, Por aí, mortos, respondeu caim, Mortos, como, mortos, porquê, Menos noé, que se afogou por sua livre vontade, aos outros matei-os eu, Como te atreveste, assassino, a contrariar o meu projecto, é assim que me agradeces ter-te poupado a vida quando mataste abel, perguntou o senhor, Teria de chegar o dia em que alguém te colocaria perante a tua verdadeira face, Então a nova humanidade que eu tinha anunciado, Houve uma, não haverá outra e ninguém dará pela falta. Caim és, e malvado, infame matador do teu próprio irmão, Não tão 
malvado e infame como tu, lembra-te das crianças de sodoma (SARAMAGO, 2010, p. 172).

O desfecho do romance contraria totalmente a história original, uma vez que é a partir dessa nova humanidade que o desenrolar da história oficial se desenvolve. Ao traçar um novo final para sua história, a releitura propõe uma forte crítica à figura divina, uma vez que, sendo Deus malvado e infame, este não poderia propor uma nova humanidade porque a outra estava avariada com a maldade, visto que seria incoerente. Ao destruir o plano divino, Caim impele Deus a encarar própria maldade, isto é "tua verdadeira face". Entretanto, é possível verificar que, ao invés de refletir sobre si próprio, Deus continua atribuindo a culpa a Caim, alegando que os atos do humano confirmavam a maldade dele, denunciada pelo assassinato do irmão. Todavia, uma vez mais Caim permanece com seu posicionamento crítico contra Deus, denunciando a maldade divina

Esse final subversivo, proposto pelo romance de Saramago, está alinhado ao postulado de Hutcheon sobre a metaficção historiográfica que, de acordo com ela, "usa e abusa desses ecos intertextuais, inserido poderosas alusões de tais ecos e depois subvertendo esse poder por meio da ironia" (1991, p. 157). Ainda que a obra não se configure como um romance de metaficção historiográfica no sentido mais estrito e fechado do termo, o mesmo utiliza algumas nuances desse subgênero para promover a reflexão acerca da centralidade do discurso original, o Antigo Testamento.

\section{CONSIDERAÇÕES FINAIS}

Como já foi dito, nosso objetivo não era rotular o romance Caim como metaficção

historiográfica,

pois reconhecemos tanto a complexidade da obra quanto - desafio proposto pela referência bíblica. Entretanto, estabelecemos pontos de contato entre as características desse subgênero e a releitura realizada pelo autor português, releitura que se apresenta como uma leitura a contrapelo do Antigo Testamento. Ao revisitar a história original, o autor acaba por construir uma nova história, na qual discussões sobre a relação entre deidade e humanidade e diferentes significações da narrativa original são levantadas e apresentadas ao leitor.

Assim como não pretendíamos classificar de forma fechada o romance como metaficção historiográfica, também não o faremos no que tange à paródia, ainda que o mesmo apresente alguns traços desta visto que a paródia é utilizada para "questionar a autoridade de qualquer ato de escrita" (HUTCHEON, 1991, p. 169). Caim, em sua malha narrativa, principalmente por meio de seu protagonista, coloca luz sobre outra versão da história oficial, promovendo, portanto reflexões acerca da singularidade do discurso bíblico.

Com efeito, é possível concluirmos que, ao lançar mão do uso desses elementos metaficcionais historiográficos, o romance levanta "questões incontornáveis, as quais acabam por conferir à escrita romanesca nuances crítico- combativas" (ROANI, 2003, p. 99). Com a maestria habitual, Saramago costura o discurso original com o discurso literário, problematizando o status do texto oficial por meio das críticas presentes em sua releitura.

\section{NOTAS}

[1] A outra vertente seria a que contempla histórias alternativas, o "futuro do passado" (HUTCHEON, 1991)

[2] A conceituação sobre metaficção historiográfica é bastante complexa mas para fins desse artigo, partiremos das considerações postuladas por Linda Hutcheon, na obra A Poética do Pós-modernismo publicada em 1988.

[3] Refere-se a uma religião monoteista

fundada na então Pérsia (atual Irã) por Bahá'u'lláh, no século XIX. Prega a unidade de Deus, das religiões (todas seriam formas da mesma fé) e da humanidade (todos os humanos são guais)

[4]Trata-se de uma autorização dada por determinadas autoridades eclesiástica, a fim de que o texto possa ser impresso, apresentando-se, em geral, no verso da folha de rosto

[5] O autor português José Saramago não utiliza a capitalização em substantivos próprios, por isso, optamos por manter a forma escrita no original: com letra minúscula.

[6] Palavra francesa pejorativa, de significado semelhante a "novo-rico", com ênfase na postura ignorante e sem consciência de classe. 


\section{REFERÊNCIAS}

ARNAUT, Ana Paula. Novos rumos na ficção de José Saramago: os romances fábula: (As Intermitências da Morte, A Viagem do Elefante, Caim). Ipotesi, 15(1), p.25-37, 2011. Disponível em: < https://bit.ly/2X97YLS>. Acesso em 30 maio 2018.

BÍBLIA Português. Velho Testamento e Novo Testamento. Tradução de Ivo Storniolo e Euclides Martins Balancin. São Paulo: Paulus, 1998

DUBY, Georges. Idade Média, Idade dos Homens. São Paulo: Companhia das Letras, 2011

FOLEY, Barbara. Telling the Truth: The Theory and Practice of Documentary Fiction. Ithaca, NY e Londres: Cornell University Press, 1986.

HUTCHEON, Linda. Poética do pósmodernismo: história, teoria, ficção. Rio de Janeiro: Imago Ed, 1991.

LUKÁCS, Georg. The Historical Novel. Londres: Merlin, 1962

ROANI, Gerson Luiz. Espaços que a história tece na ficção de Saramago, Letras, 27, p.99-110, 2003.

SARAMAGO, José. Caim. São Paulo: Companhia das Letras, 2010.

THIHER, Allen. Words in reflection: modern language theory and postmodern fiction. Chicago: University of Chicago Press, 1984.

\section{Artigo recebido em: 15 Jan. 2020. I Artigo aprovado em: 04 Maio 2020.}

[i] É doutoranda e mestra em Letras: Estudos Literários pela Universidade Estadual de Maringá - UEM. Aluna do Programa de Pós-Graduação Lato Sensu em Estudos Literários pela Universidade Estadual do Paraná - Unespar - Campus de Campo Mourão. Graduada em Letras Português/Inglês pela mesma instituição.

Orcid: https://orcid.org/0000-0001-6231-701X.

E-mail: anazukoski@gmail.com

[ii] É doutora em Letras pela Universidade Estadual Paulista Júlio de Mesquita Filho, com pós-doutorado pela Rutgers - the State University of New Jersey. Professora associada no Departamento de Teorias Linguísticas e Literárias na Universidade Estadual de Maringá.

Orcid: https://orcid.org/0000-0002-9692-7374

E-mail:mcsilva5@uem.br 